\title{
Impaired antioxidant defenses and DNA damage in the European glass eel (Anguilla anguilla) exposed to ocean warming and acidification
}

\author{
Ana Rita Lopes ${ }^{\mathrm{a}, \mathrm{b}, 1}$, Cátia Figueiredo a,c,d,1 ${ }^{\text {Eduardo Sampaio }}{ }^{\mathrm{e}}$, Mário Diniz ${ }^{\mathrm{d}}$, Rui Rosa ${ }^{\mathrm{e}}$, Tiago F. Grilo ${ }^{\mathrm{a}, *}$ \\ a MARE - Marine and Environmental Sciences Centre, Faculdade de Ciências da Universidade de Lisboa, Campo Grande, 1749-016 Lisboa, Portugal \\ ${ }^{\mathrm{b}}$ MARE - Marine and Environmental Sciences Centre, ISPA - Instituto Universitário, Rua Jardim Do Tabaco 34, 1149-041 Lisboa, Portugal \\ c Division of Environmental Oceanography and Bioprospection, IPMA - Portuguese Institute for Sea and Atmosphere, Av. Brasília, 1449-006 Lisboa, Portugal \\ d UCIBIO, REQUIMTE, Departamento de Química, Faculdade de Ciências e Tecnologia, Universidade Nova de Lisboa, Quinta da Torre, 2829-516 Caparica, Portugal \\ e MARE - Marine and Environmental Sciences Centre, Laboratório Marítimo da Guia, Faculdade de Ciências da Universidade de Lisboa, Avenida Nossa Senhora do Cabo 939, 2750-374 Cascais, Portugal
}

\section{H I G H L I G H T S}

- European glass eels were lab-exposed to future warming and acidification conditions.

- Selected biomarkers were used to study physiological responses of glass eels.

- The antioxidant enzymatic machinery was impaired in the muscle and viscera.

- Heat shock response was different between tissues, increasing with temperature.

- The results emphasize the higher vulnerability of eels under climate change.

\section{A R T I C L E I N F O}

\section{Article history:}

Received 9 October 2020

Received in revised form 5 January 2021

Accepted 25 January 2021

Available online 11 February 2021

Editor: Daniel Wunderlin

\section{Keywords:}

Glass eel

Early-life stages

Climate change

Biomarkers

Oxidative stress

Heat shock response

\section{G R A P H I C A L A B S T R A C T}

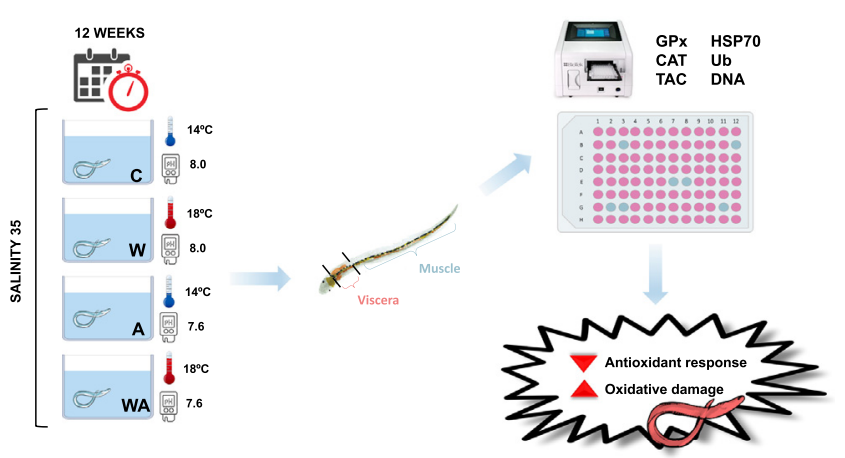

\section{A B S T R A C T}

The European eel (Anguilla anguilla) has attracted scientific inquiry for centuries due to its singular biological traits. Within the European Union, glass eel fisheries have declined sharply since 1980, from up to $2000 \mathrm{t}(\mathrm{t})$ to $62.2 \mathrm{t}$ in 2018, placing wild populations under higher risk of extinction. Among the major causes of glass eels collapse, climate change has become a growing worldwide issue, specifically ocean warming and acidification, but, to our knowledge, data on physiological and biochemical responses of glass eels to these stressors is limited. Within this context, we selected some representative biomarkers [e.g. glutathione peroxidase (GPx), catalase (CAT), total antioxidant capacity (TAC), heat shock proteins (HSP70), ubiquitin (Ub) and DNA damage] to study physiological responses of the European glass eel under distinct laboratory-climate change scenarios, such as increased water temperature $\left(+4^{\circ} \mathrm{C}\right)$ and $\mathrm{pH}$ reduction $(-0.4$ units), for 12 weeks. Overall, the antioxidant enzymatic machinery was impaired, both in the muscle and viscera, manifested by significant changes in CAT, GPX and TAC. Heat shock response varied differently between tissues, increasing with temperature in the muscle, but not in the viscera, and decreasing in both tissues under acidification. The inability of HSP to maintain functional protein conformation was responsible for boosting the production of Ub, particularly under warming and acidification, as sole stressors. The overproduction of reactive oxygen species (ROS), either elicited by warming - due to increased metabolic demand - or acidification - through $\mathrm{H}^{+}$interaction with $\mathrm{O}_{2}^{-}$, generating $\mathrm{H}_{2} \mathrm{O}_{2}$ - overwhelmed defense mechanisms, causing oxidative stress and consequently leading to protein and DNA damage. Our results emphasize the vulnerability of eels' early life stages to climate change, with potential cascading consequences to adult stocks.

(c) 2021 Elsevier B.V. All rights reserved.

\footnotetext{
* Corresponding author.

E-mail address: tfgrilo@fc.ul.pt (T.F. Grilo).

${ }^{1}$ Equally contributed.
} 


\section{Introduction}

Wild populations of the European eel (Anguilla anguilla) are facing a serious risk of extinction and have been classified as 'critically endangered' by the International Union for the Conservation of Nature (IUCN) for more than a decade. Recruitment of European glass eels (i.e. the postlarval phase corresponding to the freshwater colonizing stage arriving from the southwestern part of the Sargasso Sea, where reproduction takes place, to continental waters) collapsed dramatically from the early 1980 's onwards, from up to $2000 \mathrm{t}$ (t) to $62.2 \mathrm{t}$ in 2018 (ICES, 2019). The declining trend in juvenile eel recruitment has sparked significant scientific inquiry and it is consensual that anthropogenic pressure is greatly contributing for this collapse. In fact, Drouineau et al. (2018) summarized five main drivers for eels decline: i) overexploitation at all their stages; ii) fragmentation and habitat loss; iii) increased contamination load; iv) alien parasitoid species (e.g. Anguillicola crassus); and v) global warming and oceanic physical modifications.

Some studies have reported the adverse effects of climate change not only on hatching and subsequent survival of eel larvae (strongly correlated with food availability) (Bonhommeau et al., 2008a; Bonhommeau et al., 2008b), but also on recognition of olfactory cues affecting their homing ability and habitat selection (Borges et al., 2019). The spawning migration of silver eels showed to be affected by alterations in river discharges and precipitation regimes (Drouineau et al., 2017, 2018; Durif et al., 2003).

At glass eel stage, recent research revealed that ocean warming (OW) decreased survival and increased migratory activity, while ocean acidification (OA) appears to hinder migratory response, reducing the preference for riverine cues (Borges et al., 2019). However, in the light of rapid environmental changes and from a biochemical perspective, several issues remain unsolved. It is well known that exposure to OW and OA can be quite challenging to fish physiology and ecology, especially for early life stages that are suspected to be more vulnerable to future ocean conditions (Pankhurst and Munday, 2011). For example, while fish embryos generally tolerate a narrow temperature range and commonly exhibit increased mortality, growth and developmental rates under OW (Rombough, 1997), responses of fish early life stages may be more variable and interspecific when subjected to OA.

Thermal stress and acidification could exert the formation of reactive oxygen species (ROS) during several cellular pathways of aerobic metabolism that can lead to protein damage, nucleic acids' structure abnormalities and lipid peroxidation (Lesser, 2006). The most common ROS are the singlet oxygen $\left({ }^{1} \mathrm{O}_{2}\right)$, the superoxide anion $\left(\mathrm{O}_{2}^{-}\right)$, the hydrogen peroxide $\left(\mathrm{H}_{2} \mathrm{O}_{2}\right)$ and the hydroxyl radical $(\mathrm{HO} \bullet)$, that can rapidly react and generate other toxic compounds, such as the peroxynitrite (HOONO), hypochloric acid ( $\mathrm{HOCl}$ ), peroxyl radicals ( $\mathrm{ROO} \bullet$ ) and alkoxyl radicals (RO•) (Regoli and Giuliani, 2014). The mitigation of adverse effects caused by excess of ROS in cells requires the activation of a wide array of low molecular weight scavengers and antioxidant enzymes, such as superoxide dismutase (SOD), catalase (CAT) and glutathione peroxidase (GPx), whose functions prevent organisms from oxidative stress (Regoli and Giuliani, 2014). Besides the antioxidant defense system, tissue-specific heat shock proteins (HSPs), usually correlated with thermal stress (Cardoso et al., 2017; Grilo et al., 2018; Sampaio et al., 2018), jointly with ubiquitin (Ub) (Lopes et al., 2019), help to repair, refold and eliminate damaged or denatured proteins, as well as protect and control ROS formation (Sokolova et al., 2011).

Despite significant knowledge advances on survival and riverward migration of glass eels under a climate change scenario and salinity gradients, the biochemical and physiological responses facing these stressors remain poorly understood. Scarce information exists on the characterization of the physiological health status of glass eels (i.e. through determination of biochemical markers), being mostly restricted to pollution by mercury (Bolliet et al., 2017; Castro et al., 2018; Claveau et al., 2015), metals and polycyclic aromatic hydrocarbons (PAHs) (Gravato et al.,
2010), hypoxia and cadmium (Pierron et al., 2007), and lanthanum (Figueiredo et al., 2018, 2020). To the best of our knowledge, no studies have yet evaluated the physiological health status of glass eels in a long-term exposure to increased temperature and acidification. Therefore, in order to fill this gap, the present study adds new insights to previous evidence of Borges et al. (2019), aiming to unveil the physiological health status of endangered glass eels after a long-term exposure (i.e. 12 weeks) to single and combined $\mathrm{OW}\left(+4{ }^{\circ} \mathrm{C}\right)$ and $\mathrm{OA}(-0.4 \mathrm{pH}$ units), by using a battery of biomarkers [e.g. glutathione peroxidase (GPX), catalase (CAT) total antioxidant capacity (TAC), HSP70, Ub and DNA damage] that will provide a holistic perspective over biochemical pathways occurring in European glass eels, under laboratory-simulated climate change scenarios.

\section{Material and methods}

\subsection{Sampling site and laboratory maintenance}

European glass eels were captured at the mouth of the Minho River Estuary ( $41^{\circ} 53^{\prime} 26.33^{\prime \prime} \mathrm{N} 8^{\circ} 49^{\prime} 30.98^{\prime \prime} \mathrm{W}$, Portugal), in January 2017 , with collaboration of local fishermen, by using hand-held dip and stow nets. Physicochemical parameters registered at the time of capture were: salinity $=35$; temperature $=13.7^{\circ} \mathrm{C}$ and water $\mathrm{pH}=8.02$. Afterwards, organisms were transported to Laboratório Marítimo da Guia aquaculture facilities (Cascais, Portugal) in temperature-controlled tanks filled with continuously aerated seawater from the collection site. Upon arrival to the aquaculture facilities, glass eels were laboratory-acclimated for two weeks under seawater conditions mimicking those at the collection site.

\subsection{Experimental design}

Glass eels were randomly allocated to one of the following experimental treatments, as described in supplementary information of Borges et al. (2019), aiming to reflect present-day conditions at the collection site and predicted OW and OA scenarios by 2100 (IPCC, 2014): i) control (C; $\left.14{ }^{\circ} \mathrm{C}, \mathrm{pH} 8.0\right)$; ii) acidification $\left(\mathrm{A} ; 14{ }^{\circ} \mathrm{C}, \mathrm{pH} 7.6\right)$; iii) warming (W; $\left.18^{\circ} \mathrm{C}, \mathrm{pH} 8.0\right)$; iv) warming and acidification (WA; $18^{\circ} \mathrm{C}, \mathrm{pH}$ 7.6). In order to accomplish experimental conditions reflecting future climate change scenarios to which organisms would be exposed for 12 weeks, temperature and water $\mathrm{pH}$ were gradually adjusted over a week, at a rate of $0.5^{\circ} \mathrm{C}$ and $0.05 \mathrm{pH}$ units per day, respectively. Individuals were distributed into four replicate tanks, each with a volume of $15 \mathrm{~L}$-aerated water, per treatment, for 12 weeks, at salinity 35 , and a fixed photoperiod of $12 \mathrm{~h}: 12 \mathrm{~h}$ (light/dark). Animals were fed cod roe ad libitum every two days.

Water temperature was regulated using chillers (FRIMAR, Fernando Ribeiro Lda., Portugal) and submergible water heaters (Eheim, Germany). Water acidification set-up followed standard acidification experimental design guidelines (Cornwall and Hurd, 2016). Any pH variation was permanently monitored in each replicate using a pH probe (GHL, Germany) connected to an automated controller (Profilux 3.1, GHL, Germany) - calibrated with TRIS-HCI (TRIS) and 2Aminopyridine $\mathrm{HCl}$ (AMP) seawater buffers - which adjusted $\mathrm{pH}$ values every two seconds. The $\mathrm{pH}$ water balance in each replicate was achieved by downregulation, with injection of a certified $\mathrm{CO}_{2}$ gas mixture (Air Liquide, Portugal), via solenoid valves (Etopi, Portugal), and pH upregulation was ensured by injection of atmospheric air. Measurements of water temperature (TFX 430, WTW GmbH, Germany) and pH (SevenGo pro SG8, Mettler Toledo) were performed on a daily basis. Seawater carbonate system speciation (Table S1) was calculated weekly from total alkalinity $(\mathrm{TA} ; \lambda=595 \mathrm{~nm}$ ) (Sarazin et al., 1999) and other parameter measurements. Total dissolved inorganic carbon $(\mathrm{CT}), \mathrm{pCO}_{2}$, bicarbonate concentration and aragonite saturation levels were calculated using the CO2SYS software (Lewis and Wallace, 1998). A flow-through system ensured continuous low-flux seawater renewal to each replicate, 
maintaining overall water quality and the maintenance of TA and adequate CT speciation. Water quality was further ensured using protein skimmers (Macroaqua, China), wet-dry filters, and 30-W UV-sterilizers (TMC, Chorleywood, UK). Ammonia, nitrite and nitrate levels were monitored regularly by means of colorimetric tests (Profi Test, Salifert, Holland) and kept below detection levels. The rearing tanks were inspected daily, and mortality checked (please see Borges et al., 2019). Salinity was regularly monitored using a refractometer (TMC Iberia, Portugal). Survival was daily inspected along the 12-week exposure period and decreased significantly with warming regardless $\mathrm{pH}$ conditions (for further details on survival see Borges et al., 2019).

\subsection{Biomarker analyses}

\subsubsection{Preparation of tissue extracts}

Following procedures described in Borges et al. (2019) we randomly collected 16 individuals per treatment $(n=4$ per replicate) from a total of 400 individuals for all the treatments ( 25 individuals per replicate $\times 4$ replicates per treatment $\times 4$ treatments) at the beginning of the exposure experiment. Afterwards they were sacrificed and immediately frozen at $-80^{\circ} \mathrm{C}$ for subsequent biomarkers analyses. We only focused on glass eels' enzymatic machinery responses exclusively in saltwater, reflecting the period during which they arrive and remain in coastal areas and estuaries, before settling in rivers and lakes.

Frozen samples were divided into two body parts: viscera (containing the internal organs) and muscle. Subsequently, they were homogenized using an Ultra-Turrax (Staufen, Germany), in $2 \mathrm{~mL}$ of phosphate buffered saline solution (PBS: $0.14 \mathrm{M} \mathrm{NaCl}, 2.7 \mathrm{mM} \mathrm{KCl}, 8.1 \mathrm{mM}$ $\mathrm{Na}_{2} \mathrm{HPO}_{4}$ and $\left.1.47 \mathrm{mM} \mathrm{KH} \mathrm{PO}_{4}, \mathrm{pH} 7.4\right)$ and the crude homogenates were centrifuged at $10,000 \times \mathrm{g}$ for $15 \mathrm{~min}$ at $4{ }^{\circ} \mathrm{C}$, according to Lopes et al. (2019). The supernatants were immediately frozen and kept at $-80^{\circ} \mathrm{C}$ until further analyses. Each sample was run in triplicate (technical replicates), and the results were normalized to total protein content, as described by Bradford (1976).

\subsubsection{Enzymatic activities and total antioxidant capacity (TAC)}

Antioxidant enzymes, such as catalase (CAT), glutathione peroxidase (GPx) and total antioxidant capacity (TAC) were measured in the cytosolic fractions from muscle and viscera tissues, according to our previous studies (Lopes et al., 2019; Lopes et al., 2018; Lopes et al., 2013; Sampaio et al., 2018).

Specifically, to determine CAT activity, $20 \mu \mathrm{L}$ of each sample, as well as $100 \mu \mathrm{L}$ of potassium phosphate $(100 \mathrm{mM})$ and $30 \mu \mathrm{L}$ of methanol were added to a 96-well microplate, that was incubated and shaken for $20 \mathrm{~min}$. Subsequently, $30 \mu \mathrm{L}$ of $10 \mathrm{M}$ potassium hydroxide and $30 \mu \mathrm{L}$ of $34.2 \mathrm{mM}$ Purpald (in $0.5 \mathrm{M} \mathrm{HCl}$ ) were added to each well, and plates shaken and incubated for another $10 \mathrm{~min}$. Finally, a last 5-min incubation was performed, with $10 \mu \mathrm{L}$ of $65.2 \mathrm{mM}$ Potassium periodate (in $0.5 \mathrm{M} \mathrm{KOH}$ ) and the absorbance read at $540 \mathrm{~nm}$ (Synergy HTX MiltiMode Microplate Reader, BioTek Instruments, USA). A Formaldehyde calibration curve $(0-75 \mu \mathrm{M})$ was used to quantify samples formaldehyde concentration, followed by the calculation of CAT activity in each sample.

To calculate GPx (EC 1.11.1.9) activity, $20 \mu \mathrm{L}$ of each sample, $50 \mathrm{mM}$ Phosphate buffer ( $\mathrm{pH} 7.6$ ), co-substrate mixture (0.8 Mm $\beta$-NADPH, $4 \mathrm{mM}$ Glutathione, $4 \mathrm{U} / \mathrm{mL}$ Glutathione reductase, and $4 \mathrm{mM}$ Sodium azide) and $15 \mathrm{mM}$ Cumene hydroperoxide $\left(\mathrm{C}_{9} \mathrm{H}_{12} \mathrm{O}_{2}\right)$ were added to each well, and the absorbance was read each minute, for a total of $6 \mathrm{~min}$, at $340 \mathrm{~nm}$ (Synergy HTX Milti-Mode Microplate Reader, BioTek Instruments, USA).

A Trolox calibration curve $(0-0.3 \mathrm{mM})$ was used to calculate TAC. Specifically, each sample $(10 \mu \mathrm{L})$ was added to each well in a 96-well microplate, followed by $10 \mu \mathrm{L}$ of $90 \mu \mathrm{M}$ Myoglobin, $150 \mu \mathrm{L}$ of $600 \mu \mathrm{M}$ 2,2'-Azino-bis (3-ethylbenzothiazoline-6-sulphonic acid) and $40 \mu \mathrm{L}$ of $500 \mu \mathrm{M}$ Hydrogen peroxide. Microplates were then incubated for
5 min and the absorbance was read at $410 \mathrm{~nm}$ (Synergy HTX MiltiMode Microplate Reader, BioTek Instruments, USA).

\subsubsection{Heat shock protein and ubiquitin levels}

Heat Shock Protein 70 (HSP) levels were determined through an ELISA according to Njemini et al. (2005). Briefly, $10 \mu \mathrm{L}$ of each sample was diluted in $980 \mu \mathrm{L}$ Phosphate-buffered saline (PBS). Subsequently, $100 \mu \mathrm{L}$ of each diluted sample was added to 96-well microplates (Microlon 600, Greiner Bio-One, Austria) and allowed to incubate overnight at $4{ }^{\circ} \mathrm{C}$. On the subsequent day, microplates were washed $(3 \times)$ using PBS containing 0.05\% TWEEN-20. Afterwards, $100 \mu \mathrm{L}$ of blocking solution [1\% Bovine serum albumin (BSA)] was added to each well, and microplates were incubated for $90 \mathrm{~min}$ at $37^{\circ} \mathrm{C}$. Afterwards, $50 \mu \mathrm{L}$ of primary antibody ( $5 \mu \mathrm{g} \mathrm{mL} \mathrm{m}^{-1}$ in $1 \% \mathrm{BSA}$ : anti-HSP70/HSC70, Acris, USA) was added to each well. After another incubation period (overnight at $4{ }^{\circ} \mathrm{C}$ ), microplates were washed $(3 \times)$ to remove nonlinked antibodies and a second antibody [alkaline phosphataseconjugated anti-mouse IgG (Fab specific, Sigma-Aldrich, USA)] was added ( $50 \mu \mathrm{L}$ of $1 \mu \mathrm{g} \mathrm{mL}^{-1}$ ) to each well, and microplates allowed to incubate at $37^{\circ} \mathrm{C}$ for $90 \mathrm{~min}$. After an additional washing procedure, $100 \mu \mathrm{L}$ of substrate (SIGMA FAST ${ }^{\mathrm{TM}} p$-Nitrophenyl Phosphate Tablets, Sigma-Aldrich, USA) was added to each well and incubated for $30 \mathrm{~min}$ at room temperature. Afterwards, $50 \mu \mathrm{L}$ of stop solution ( $3 \mathrm{M} \mathrm{NaOH}$ ) was added to each well and the absorbances read at $405 \mathrm{~nm}$ (Synergy HTX Milti-Mode Microplate Reader, BioTek Instruments, USA). HSP content was calculated from the calibration curve, based on serial dilutions of purified HSP70 active protein (0-2000 $\mu \mathrm{g} \mathrm{mL} \mathrm{L}^{-1}$, Acris, USA) and results normalized to sample protein ( $\mu \mathrm{g} / \mathrm{mg}$ total protein).

Ubiquitin (Ub) content was assessed through a direct ELISA, according to Lopes et al. (2018). Each sample (100 $\mu \mathrm{L})$ was added to 96-well microplates (Microlon 600, Greiner Bio-One, Austria) and incubated overnight at $4{ }^{\circ} \mathrm{C}$. On the next day microplates were washed $(3 \times)$ with PBS-TWEEN. Afterwards, $100 \mu \mathrm{L}$ of blocking solution [1\% Bovine serum albumin (BSA)] was added to each well and microplates were allowed to incubate for $90 \mathrm{~min}$ at $37^{\circ} \mathrm{C}$. Subsequently, $50 \mu \mathrm{L}$ of primary antibody (P4D1, sc-8017, HRP conjugate, Santa Cruz, USA) was added to each well, and after another incubation period (overnight at $4{ }^{\circ} \mathrm{C}$ ), microplates were washed $(3 \times)$ to remove non-linked antibodies. Afterwards, $100 \mu \mathrm{L}$ of TMB/E substrate (Temecula California, Merck Millipore) was added to each well and incubated for $30 \mathrm{~min}$ at room temperature. Finally, $100 \mu \mathrm{L}$ of stop solution (1 M HCL) was added to each well and the absorbances were read at $415 \mathrm{~nm}$, using a microplate reader (Synergy HTX Milti-Mode Microplate Reader, BioTek Instruments, USA). The Ub content was assessed based on a serial dilution of purified ubiquitin (0-1.0 $\mu \mathrm{g} \mathrm{mL} \mathrm{m}^{-1}$, UbBio, E-1100, USA) and results expressed according to total sample protein ( $\mu \mathrm{g} / \mathrm{mg}$ total protein).

\subsubsection{Acid nucleic damage}

DNA damage was measured as previously described by Maclouf et al. (1987) and Shen et al. (2007) through an ELISA method, via the quantification of 8-hydroxy-2'-deoxyguanosine (8-OHdG). Each sample ( $100 \mu \mathrm{L})$ was added to each well in a 96-well microplate and allowed to incubate overnight at $4{ }^{\circ} \mathrm{C}$. On the subsequent day, plates were washed $(3 \times)$ with PBS-TWEEN 20 and $200 \mu \mathrm{L}$ of the blocking solution (BSA) was added to each well and allowed to incubate for $90 \mathrm{~min}$ at room temperature. After another washing procedure, microplates were incubated overnight with primary antibody (anti-OHdG, clone 15 A3, Sigma-Aldrich, Germany). Subsequently, microplates were washed to remove nonlinked antibody and allowed to incubate for $90 \mathrm{~min}$ at $37^{\circ} \mathrm{C}$ with the secondary antibody (alkaline phosphatase-conjugated anti-mouse IgG, Fab specific, Sigma-Aldrich, USA). After a final washing procedure, plates were incubated at room temperature for 30 min after adding $100 \mu \mathrm{L}$ of substrate (SIGMA FAST ${ }^{\mathrm{TM}}$ p-Nitrophenyl Phosphate Tablets, SigmaAldrich, USA) to each well, and the reaction stopped by adding $100 \mu \mathrm{L}$ of $3 \mathrm{M} \mathrm{NaOH}$. The absorbance was read at $405 \mathrm{~nm}$ using a microplate reader (Synergy HTX Milti-Mode Microplate Reader, BioTek Instruments, 
USA), and results expressed according to the total protein in sample (abs $\mathrm{mg}^{-1}$ total protein).

\subsection{Statistical analysis}

Generalized linear mixed models (GLMMs) analyses were used to infer significant differences between replicate tanks within each treatment, for each tissue (i.e. muscle and viscera) and dependent variable (i.e. GPX, CAT, TAC, HSP, Ub, and 8-OHdG). Whenever no significant differences were found between replicate tanks, the random effect of the tank was removed from the models. Data was fitted using Gaussian family and model residuals checked for homogeneity of variances and normality, as well as independence and leverage of residuals to perform model validation. Whenever the assumptions were not fulfilled, we changed to Gamma family models, and model validation was evaluated using the abovementioned procedure. All statistical analyses were performed using the "lme4" and "nlme" packages on R studio (R Core Team, 2018).

\section{Results}

With respect to the antioxidant enzymatic machinery, GPx activity (Fig. 1a) exhibited significant differences within the muscle, registering lower levels when exposed to acidification alone (A; $p<0.001$, GLMM analysis in Table SII) and in combination with warming (WA; $p<0.001$, GLMM analysis in Table SII). Within the viscera GPx activity decreased with warming (W; $p<0.05$, GLMM analysis in Table SII), acidification ( $\mathrm{A} ; p<0.001$, GLMM analysis in Table SII) and with both stressors combined (WA; $p<0.001$, GLMM analysis in Table SII).

A similar scenario occurred with CAT activity (Fig. 1b) within the muscle, which declined under exposure to warming (W; $p<0.001$, GLMM analysis in Table SIII), acidification (A; $p<0.05$, GLMM analysis in Table SIII), and warming and acidification (WA; $p<0.05$, GLMM analysis in Table SII). For the viscera, only warming (W; $p<0.001$, GLMM analysis in Table SIII) and acidification (A; $p<0.05$, GLMM analysis in Table SIII), as sole stressors, caused an inhibition of CAT activity.

Regarding TAC (Fig. 1c) the levels diminished with warming (W; $p<0.001$, GLMM analysis in Table SIV), acidification (A; $p<0.001$, GLMM analysis in Table SIV) and the combined treatment (WA; $p<0.001$, GLMM analysis in Table SIV), within the muscle, while no significant alterations were found in the viscera $(p>0.05$ for all treatments, GLMM analysis in Table SIV).

The heat shock response (HSP; Fig. 2a) increased with warming (W; $p<0.05$, GLMM analysis in Table SV) within the muscle and declined with acidification (A; $\mathrm{p}<0.05$, GLMM analysis in Table SV). For the viscera, alterations in heat shock response were only observed under acidification, causing a significant reduction (A; $p<0.001$, GLMM analysis in Table SV).

The overall decrease in the antioxidant enzymatic machinery and HSP levels translated into oxidative damage. More specifically, warming and acidification as sole stressors rose Ub levels $(p<0.001$ for both $\mathrm{W}$ and A, GLMM analysis in Table SVI) - an indirect protein damage marker - in the muscle. Nonetheless, Ub levels diminished with warming and acidification (WA; $p<0.05$, GLMM analysis in Table SVI) within the same tissue. In the viscera, warming (W; $\mathrm{p}<0.001$, GLMM analysis in Table SVI) and acidification (A; p < 0.05, GLMM analysis in Table SVI) stimulated production of Ub.

Evidence of DNA damage was present in the muscle under warming (W; $p<0.001$, GLMM analysis in Table SVII) while the viscera revealed higher levels of 8-OHdG (as a proxy of DNA damage) under exposure to warming (W; $p<0.001$, GLMM analysis in Table SVII), acidification (A; $p<0.05$, GLMM analysis in Table SVII), both individually, and as combined stressors (WA; $p<0.05$, GLMM analysis in Table SVII). a
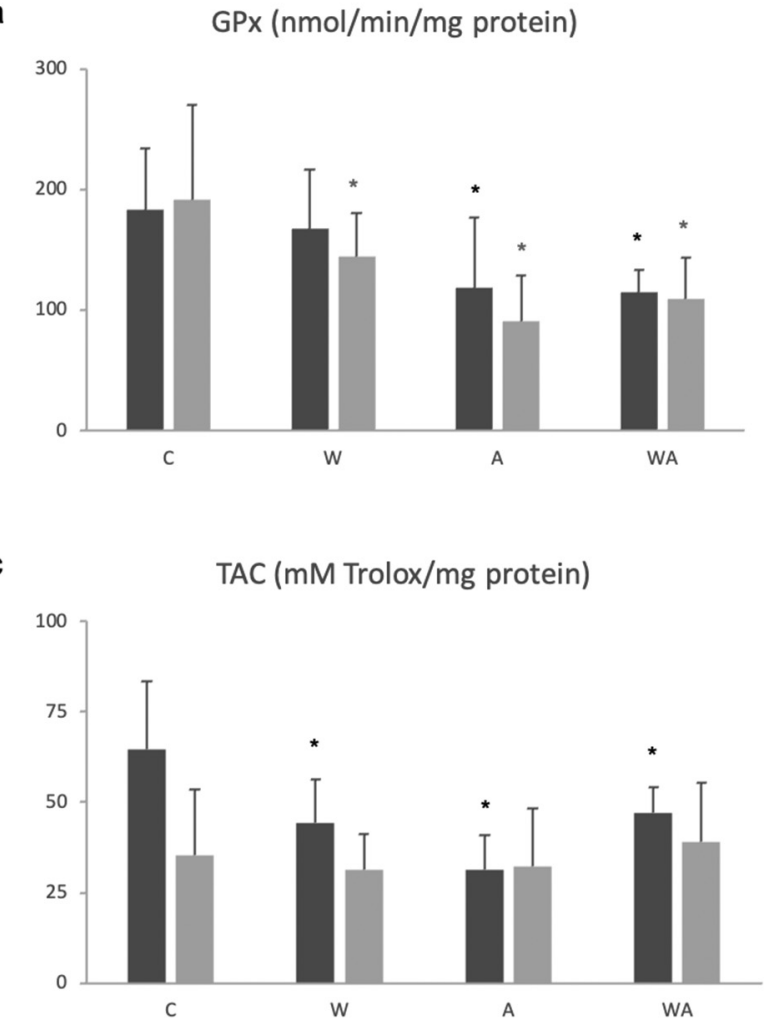

b CAT (nmol/min/mg protein)

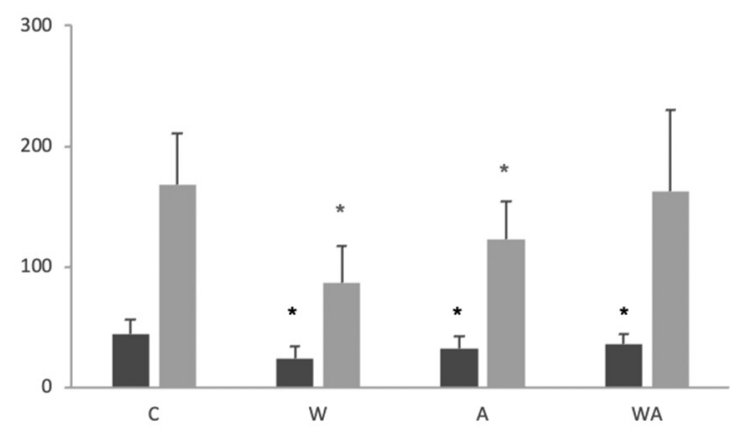

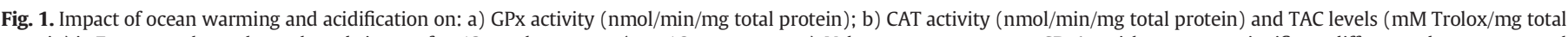

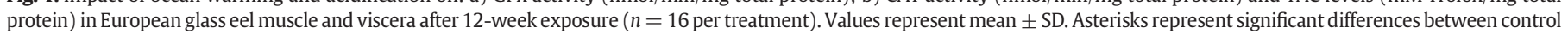
(C) and each treatment conditions [warming (W), acidification (A), warming and acidification (WA)], within each tissue. 

HSP ( $\mu \mathrm{g} / \mathrm{mg}$ protein)
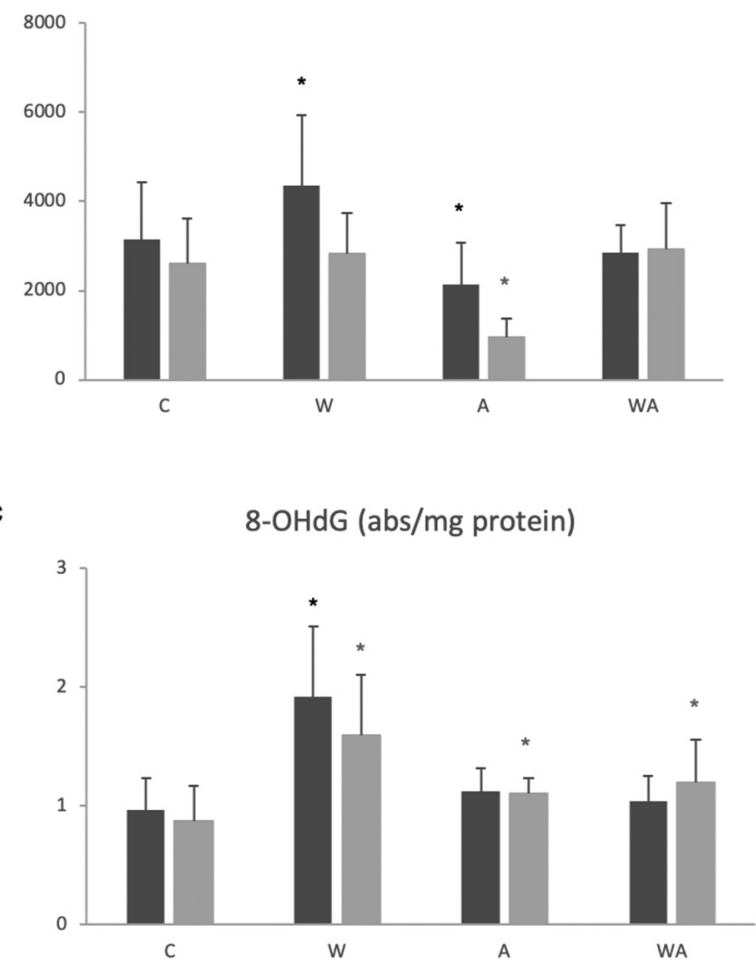

b

Ub ( $\mu \mathrm{g} / \mathrm{mg}$ protein)

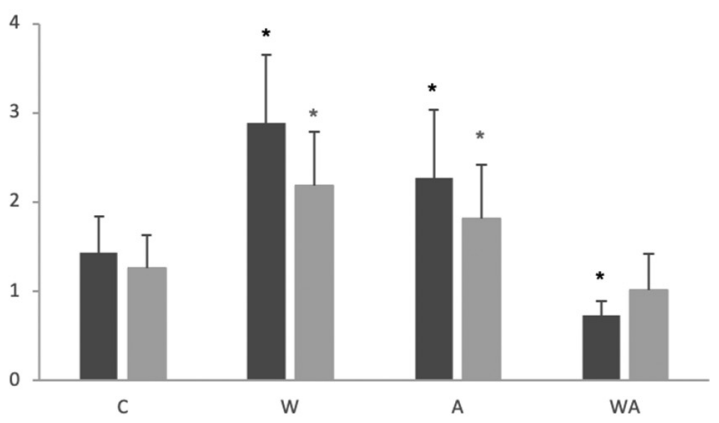

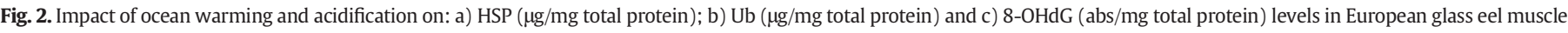

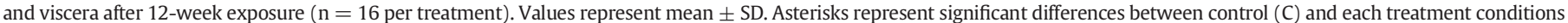
[warming (W), acidification (A), warming and acidification (WA)], within each tissue.

\section{Discussion}

In a context of global changes, a previous study from our research team (Borges et al., 2019) demonstrated that temperature was the main driver affecting glass eel's survival. An increase of $4{ }^{\circ} \mathrm{C}$ in water temperature resulted in higher glass eel mortality, while OA played a minor role on eels survival (see Borges et al., 2019). In fact, the bulk of knowledge gathered on fish physiology (i.e. growth, development and mortality) states highly variable results among fish species to OArelated conditions. On the other hand, the body of research on the negative effects of $\mathrm{OA}$ on fish behavior seems more coherent (Heuer and Grosell, 2014). Taking that into consideration, it was expected that OA would also affect the eel's migratory response. Borges et al. (2019) demonstrated that OA dampened the effects of OW (i.e. increased migratory response in $\mathrm{OW}$-acclimated organisms), lowering the number of migrating individuals.

Notwithstanding, most studies conducted on the effects of climate change on glass eels have only focused on two levels, i.e. ecophysiology and behavior, while the cellular level has been overlooked. Herein we observed an overall decrease in the antioxidant machinery (i.e. GPx, CAT and TAC) in all treatments, for both tissues. This could suggest one of two hypotheses: i) the exceptional tolerance of the European glass eel towards extreme conditions would be reflected on its antioxidant response, decreasing the enzymatic response without causing oxidative damage; ii) OW and OA would cause an imbalance between oxidants and antioxidants, in favor of the former, impairing A. anguilla antioxidant response. In fact, our study revealed that the overproduction of ROS seems to exceed the capacity of detoxification by the antioxidant machinery, causing protein and DNA damage on our specimens, after 12 weeks exposure to predicted climate change conditions by the end of the century.

Differential heat shock response (HSR) was observed between tissues depending on the climate change stressor. HSR increased with temperature in the muscle, but not in the viscera, and decreased in both tissues with acidification. HSP are specific molecular chaperones responsible for "house-keeping" functions in the cell, such as: i) protein repair and refold mechanisms; ii) protein aggregation and unfolding evasion, and iii) denatured proteins removal. It has been proven that HSP are highly dependent on temperature, increasing their levels with warming (Grilo et al., 2018; Sampaio et al., 2018), while decreases in seawater $\mathrm{pH}$ usually play a minor role in HSR (Lopes et al., 2019; Lopes et al., 2018). However, when in combination with temperature, $\mathrm{OA}$ seems to dampen the effects observed with warming as a sole stressor (Sampaio et al., 2018). This process may be explained by the fact that $\mathrm{H}^{+}$ions, produced during the $\mathrm{CO}_{2}$ dissolution in the seawater, while reacting with free radicals produced by warming, such as $\mathrm{OH} \bullet$, will naturally be converted into water and oxygen, decreasing the amount of ROS within tissues, and therefore oxidative stress levels, and in this case restoring HSP values to control levels (Dean, 2010; Heuer and Grosell, 2014).

Despite higher HSP levels with temperature, the decrease in the antioxidant machinery with warming translated into protein and DNA damage. Moreover, the overall inactivation of protein repair and refold mechanisms (i.e. HSP) and decreased ROS detoxification processes with acidification, also culminated into increased oxidative damage. Since these processes occur as a chain reaction, we argue that the overproduction of ROS, either elicited by: i) warming - due to increased metabolic demand, that require $\mathrm{O}_{2}$ to produce ATP (Lushchak, 2011; Pamplona and Constantini, 2011) - or ii) acidification - due to the parallel increase in $\mathrm{H}^{+}$ions, and the reaction of $\mathrm{CO}_{2}$ with reactive nitrogen species (Tiedke et al., 2013; Sampaio et al., 2018) - impaired glass eel defense mechanisms. Furthermore, HSP's were unable to maintain functional protein conformation, either under the warming or acidification treatments, being responsible for the outset of the ubiquitination process, causing an increase in protein damage under those same treatments (Bond et al., 1988; Hanna et al., 2007; Sørensen et al., 2003). 
Additionally, under the combined treatment (WA), the "buffer" effect explained above was responsible to restore HSP levels to control levels, decreasing the protein damage under this scenario. Additionally, it was not surprising that increasing ROS levels caused by OW, OA or the combination of both, would also have a negative impact in eels DNA. In fact, we argue that predicted climate change conditions for 2100 could have compromised glass eel's DNA: i) directly through ROS interaction with DNA chain, causing base oxidation, base-pair disparities or singlestrand breaks, eventually triggering mutations, or ii) indirectly via protein damage, since the damage on an organism's proteome is inherently related with genome repair mechanisms (Gueranger et al., 2014; Krisko and Radman, 2013).

In conclusion, the results from the present study suggest that endcentury climate change projections are expected to cause oxidative stress, consequently leading to protein and DNA damage at A. anguilla juvenile stage. Adding this knowledge to the impacts on survival and behavior reported in Borges et al. (2019) and the fact that early life stages are at greater risk, we argue that not only climate change might reduce the amount of fully migratory individuals, but could also impair species oxidative status and population survival. Furthermore, taking into consideration that species with long lifespans, such as eels, are already classified as endangered due to anthropogenic pressures, they are probably at higher risk, as the rate of global changes could far exceed their ability to naturally adapt.

\section{CRediT authorship contribution statement}

T.F.G. and R.R. conceived and designed the experiment. C.F., E.S. and T.F.G. performed the experiment. A.R.L., C.F. and M.D. performed biomarker analyses and quantification. A.R.L. analyzed and interpreted the data. T.F.G. and A.R.L. wrote the manuscript. T.F.G. supervised and financed the work. All authors reviewed and approved the final manuscript, agreeing to be held accountable for the content herein.

\section{Ethical statement}

All experimental procedures employed in the present work were approved by the Faculdade de Ciências da Universidade de Lisboa animal welfare organization (ORBEA, Statement 5/2016) and Direção-Geral de Alimentação e Veterinária (DGAV), to fulfil the requirements imposed by the Directive 2010/63/EU of the European Parliament and of the Council of 22 September 2010 on the protection of animals used for scientific purposes.

\section{Declaration of competing interest}

The authors declare that there is no conflict of interests.

\section{Acknowledgments}

This work was supported with funds provided by the MARE strategic project (UID/MAR/04292/2019) and Fundação para a Ciência e Tecnologia (FCT) through the project CLIMATOXEEL (PTDC/AAG-GLO/ 3795/2014) and the Junior Researcher contract (CEECIND/03517/ 2017) awarded to TFG, Programa Investigador FCT 2013 to RR, Junior Researcher contract (CEECIND/00067/2018) awarded to ARL, and PhD grants attributed to CF (SFRH/BD/130023/2017) and ES (SFRH/BD/ 131771/2017). The work was also supported by the Applied Molecular Biosciences Unit-UCIBIO which is financed by national funds from FCT/ MCTES (UIDB/04378/2020). The authors are also indebted to all the colleagues who assisted in the field and laboratory work.

\section{Appendix A. Supplementary data}

Supplementary data to this article can be found online at https://doi. org/10.1016/j.scitotenv.2021.145499.

\section{References}

Bolliet, V., Claveau, J., Jarry, M., Gonzalez, P., Beaudrimont, M., Monperrus, M., 2017. Migratory behavior, metabolism, oxidative stress and mercury concentrations in marine and estuarine European eels (Anguilla anguilla). Physiol. Behav. 169, 33-40.

Bond, U.N.A., Haas, A.L., Redman, K., Schlesinger, M.J., 1988. Ubiquitin in stressed chiken embryo fibroblast. J. Biol. Chem. 263, 2384-2388.

Bonhommeau, S., Chassot, E., Planque, B., Rivot, E., Knap, A.H., Le Pape, O., 2008a. Impact of climate on eel populations of the northern hemisphere. Mar. Ecol. Prog. Ser. 373, 71-80.

Bonhommeau, S., Chassot, E., Rivot, E., 2008b. Fluctuations in European eel (Anguilla anguilla) recruitment resulting from environmental changes in the Sargasso Sea. Fish. Oceanogr. 17, 32-44.

Borges, F.O., Santos, C.P., Sampaio, E., Figueiredo, C., Paula, J.R., Antunes, C., Rosa, R., Grilo, T.F., 2019. Ocean warming and acidification may challenge the riverward migration of glass eels. Biol. Lett. 15, 20180627.

Bradford, M.M., 1976. A rapid and sensitive method for the quantitation of microgram quantities of protein utilizing the principle of protein-dye binding. Anal. Biochem. $72,248-254$.

Cardoso, P.G., Grilo, T.F., Dionisio, G., Aurélio, M., Lopes, A.R., Pereira, R., Pacheco, M., Rosa, R., 2017. Short-term effects of increased temperature and lowered pH on a temperate grazer-seaweed interaction (Littorina obtusata/Ascophyllum nodosum). Estuar. Coast. Shelf Sci. 197, 35-44.

Castro, D., Mieiro, C.L., Coelho, J.P., Guilherme, S., Marques, A., Santos, M.A., Duarte, A.C., Pereira, E., Pacheco, M., 2018. Addressing the impact of mercury estuarine contamination in the European eel (Anguilla anguilla L., 1758) - an early diagnosis in glass eel stage based on erythrocytic nuclear morphology. Mar. Pollut. Bull. 127, 733-742.

Claveau, J., Monperrus, M., Jarry, M., Pinaly, H., Baudrimont, M., Gonzalez, P., Amouroux, D., Bardonnet, A., Bolliet, V., 2015. Spatial and seasonal variations of methylmercury in European glass eels (Anguilla anguilla) in the Adour estuary (France) and relation with their migratory behavior. Environ. Sci. Pollut. Res. 22, 10721-10732.

Cornwall, C.E., Hurd, C.L., 2016. Experimental design in ocean acidification research: problems and solutions. ICES J. Mar. Sci. 73, 572-581.

Dean, J.B., 2010. Hypercapnia causes cellular oxidation and nitrosation in addition to acidosis: implications for $\mathrm{CO}_{2}$ chemoreceptor function and dysfunction. J. Appl. Physiol. 108, 1786-1795.

Drouineau, H., Bau, F., Alric, A., Deligne, N., Gomes, P., Sagnes, P., 2017. Silver eel downstream migration in fragmented rivers: use of a Bayesian model to track movements triggering and duration. Aquat. Living Resour. 30, 1-9.

Drouineau, H., Durif, C., Castonguay, M., Mateo, M., Rochard, E., Verreault, G., Yokouchi, K., Lambert, P., 2018. Endangered eels: a symbol of the effects of global change. Fish Fish. 19, 903-930.

Durif, C., Elie, P., Gosset, C., Rives, J., Travade, F., Dixon, D.A., 2003. Behavioral study of downstream migrating eels by radio-telemetry at a small hydroelectric power plant. American Fisheries Society, Symposium 33. Biology, Management, and Protection of Catadromous Eels, pp. 345-356 Bethesda, Maryland.

Figueiredo, C., Grilo, T.F., Lopes, C., Brito, P., Diniz, M., Caetano, M., Rosa, R., Raimundo, J., 2018. Accumulation, elimination and neuro-oxidative damage under lanthanum exposure in glass eels (Anguilla anguilla). Chemosphere 206, 414e423.

Figueiredo, C., Raimundo, J., Lopes, A.R., Lopes, C., Rosa, N., Brito, P., Diniz, M., Caetano, M., Grilo, T.F., 2020. Warming enhances lanthanum accumulation and toxicity promoting cellular damage in glass eels (Anguilla anguilla). Environ. Res. 191, 110051.

Gravato, C., Guimarães, L., Santos, J., Faria, M., Alves, A., Guilhermino, L., 2010. Comparative study about the effects of pollution on glass and yellow eels (Anguilla anguilla) from the estuaries of Minho, Lima and Douro Rivers (NW Portugal). Ecotoxicol. Environ. Saf. 73.

Grilo, T.F., Lopes, A.R., Sampaio, E., Rosa, R., Cardoso, P.G., 2018. Sex differences in oxidative stress responses of tropical topshells (Trochus histrio) to increased temperature and high $p \mathrm{CO}_{2}$. Mar. Pollut. Bull. 131, 252-259.

Gueranger, Q., Li, F., Peacock, M., Larnicol-Fery, A., Brem, R., Macpherson, P., Egly, J.-M., P, K., 2014. Protein oxidation and DNA repair inhibition by 6-Thioguanine and UVA radiation. J. Investig. Dermatol. 134, 1408-1417.

Hanna, J., Meides, A., Zhang, D.P., Finley, D., 2007. A ubiquitin stress response induces altered proteasome composition. Cell 129, 747-759.

Heuer, R.M., Grosell, M., 2014. Physiological impacts of elevated carbon dioxide and ocean acidification on fish. Am. J. Physiol. Regul. Integr. Comp. Physiol. 307, R1061-R1084.

ICES, 2019. Joint EIFAAC/ICES/GFCM working group on eels (WGEEL). ICES Scientific Reports. 1, 50177 pp. http://doi.org/10.17895/ices.pub.5545.

IPCC, 2014. Impacts, adaptation, and vulnerability. Summaries, frequently asked questions, and cross-chapter boxes. A contribution of Working Group II to the Fifth Assessment Report of the Intergovernmental Panel on Climate Change. In: Field, C.B., Barros, V.R., Dokken, D.J., Mach, K.J., Mastrandrea, M.D., Bilir, T.E., Chatterjee, M., Ebi, K.L., Estrada, Y.O., Genova, R.C., Girma, B., Kissel, E.S., Levy, A.N., MacCracken, S., Mastrandrea, P.R., White, L.L. (Eds.), Climate Change 2014. World Meteorological Organization, Geneva, Switzerland (p. 190 pp).

Krisko, A., Radman, M., 2013. Phenotypic and genetic consequences of protein damage. PLoS Genet. 9, e1003810.

Lesser, M.P., 2006. Oxidative stress in marine environments: biochemistry and physiological ecology. Annu. Rev. Physiol. 68, 253-278.

Lewis, E., Wallace, D.W.R., 1998. CO2SYS-Program Developed for the CO2 System Calculations.

Lopes, A.R., Trübenbach, K., Teixeira, T., Lopes, V.M., Pires, V., Baptista, M., Repolho, T., Calado, R., Diniz, M., Rosa, R., 2013. Oxidative stress in deep scattering layers: heat shock response and antioxidant enzymes activities of myctophid fishes thriving in oxygen minimum zones. Deep-Sea Res. I Oceanogr. Res. Pap. 82, 10-16. 
Lopes, A.R., Sampaio, E., Santos, C., Couto, A., Pegado, M.R., Diniz, M., Munday, P.L., Rummer, J.L., Rosa, R., 2018. Absence of cellular damage in tropical newly hatched sharks (Chiloscyllium plagiosum) under ocean acidification conditions. Cell Stress Chaperones 23, 837-846.

Lopes, A.R., Borges, F.O., Figueiredo, C., Sampaio, E., Diniz, M., Rosa, R., Grilo, T.F., 2019. Transgenerational exposure to ocean acidification induces biochemical distress in a keystone amphipod species (Gammarus locusta). Environ. Res. 170, 168-177.

Lushchak, V.I., 2011. Environmentally induced oxidative stress in aquatic animals. Aquat. Toxicol. 101, 13-30.

Maclouf, J., Grassi, J., Pradelles, P., 1987. Development of enzyme-immunoassay techniques for measurement of eicosanoids. In: Walden, T.L., Hughes, H.N. (Eds.), Prostaglandin and Lipid Metabolism in Radiation Injury. Springer, US, pp. 355-364.

Njemini, R., Demanet, C., Mets, T., 2005. Comparison of two ELISAs for the determination of Hsp70 in serum. J. Immunol. Methods 306, 176-182.

Pamplona, R., Constantini, D., 2011. Molecular and structural antioxidant defenses against oxidative stress in animals. Am. J. Physiol. Regul. Integr. Comp. Physiol. 301, R843-R863.

Pankhurst, N.W., Munday, P.L., 2011. Effects of climate change on fish reproduction and early life history changes. Mar. Freshw. Res. 62, 1062-1081.

Pierron, F., Beaudrimont, M., Gonzalez, P., Bourdinaud, J.P., Elie, P., Massabuau, J.C., 2007. Common pattern of gene expression in response to hypoxia or cadmium in the gills of the European glass eel (Anguilla anguilla). Environ. Sci. Technol. 41, 3003-3005.

R Core Team, 2018. R: A language and environment for statistical computing. R Foundation for Statistical Computing, Vienna, Austria Available from. http://www.R-project.org/.
Regoli, F., Giuliani, M.E., 2014. Oxidative pathways of chemical toxicity and oxidative stress biomarkers in marine organisms. Mar. Environ. Res. 93, 106e117.

Rombough, P.J., 1997. The effects of temperature on embryonic and larval development. In: W, C.M., D.G., M.D. (Eds.), Global warming Implications for Freshwater and Marine Fish. CambridgeUniversity Press, Cambridge, pp. 225-254.

Sampaio, E., Lopes, A.R., Francisco, S., Paula, J.R., Pimentel, M., Maulvault, A.L., Repolho, T., Grilo, T.F., Pousão-Ferreira, P., Marques, A., Rosa, R., 2018. Ocean acidification dampens physiological stress response to warming and contamination in a commercially-important fish (Argyrosomus regius). Sci. Total Environ. 618, 388-398.

Sarazin, G., Michard, G., Prevot, F., 1999. A rapid and accurate spectroscopic method for alkalinity measurements in sea water samples. Water Res. 33, 290-294.

Shen, J., Deininger, P., Hunt, J.D., Zhao, H., 2007. 8-Hydroxy-2'-deoxyguanosine (8-OHdG) as a potential survival biomarker in patients with nonsmall-cell lung cancer. Cancer 109, 574-580.

Sokolova, I.M., Sukhotin, A.A., Lannig, G., 2011. Stress effects on metabolism and energy budgets in mollusks. In: Abele, D., Zenteno-Savín, T., Vazquez-Medina, J. (Eds.), Oxidative Stress in Aquatic Ecosystems. John Wiley \& Sons, Ltd, Chichester, UK, pp. 261-280.

Sørensen, J.G., Kristensen, T.N., Loeschcke, V., 2003. The evolutionary and ecological role of heat shock proteins. Ecol. Lett. 6, 1025-1037.

Tiedke, J., Cubuk, C., Burmester, T., 2013. Environmental acidification triggers oxidative stress and enhances globin expression in zebrafish gills. Biochem. Biophys. Res. Commun. 441, 624-629. 